\title{
FORMULASI SEDIAAN SABUN MANDI PADAT EKSTRAK ETANOL BONGGOL NANAS (Ananas cosmosus L.) UNTUK KELEMBAPAN KULIT
}

\author{
Debi Dinha Octora ${ }^{1}$, Yuliana Situmorang ${ }^{2}$, Romauli Anna Teresia \\ Marbun ${ }^{3}$ \\ Institut Kesehatan Medistra Lubuk Pakam, Jalan Sudirman No.38 \\ Lubuk Pakam \\ e-mail: debi.d.o.sitepu@gmail.com \\ DOI : https://doi.org/10.35451/jfm.v2i2.369
}

\begin{abstract}
:
Stem pineapple can be formulated into a solid soap bath preparation because based on previous research, stem pineapple contain high antioxidants are represented with flavonoids and saponins. $A$ compound capable of counteracting free radicals is an antioxidant. This study uses quasi experimental method. Plant collecting, simplex making, extraction by maceration using ethanol solvent and solid soap formulation with the ethanol extract of beans each concentration which. Experimental method had done include ( $\mathrm{pH}$ test, foam height and density test ability to moisturize the skin on the respondent as much 10 people for \pm onehour by using skin analyzer tool. Esktrak of stem pineapple can be normalized into a solid soap bath preparation with $\mathrm{pH}$ test results showed 5\% higher concentration, foam test results showed a 5\% higher concentration and skin moisture examinationresults showed 5\% moist concentration. The results showed that the solid soap bath preparations from Stempineapple extract of ethanol (Ananas Cosmosus L) to moisturize the skin with different concentration variations can be formulated into a solid soap bath preparation with $\mathrm{pH}$ test results show stable on the skin, foam test results show that bath soap preparation solid qualified and skin moisture check results show 5\% moisture concentration.It is desirable for further research to make other preparations of bean extract ethanol (Ananas Cosmosus L.) in other dosage forms such as liquid soaps, lotions, tansparent soaps, creams and so on.
\end{abstract}

Keywords: Extracts of stem pineapple, moisturizes the skin, solid bath soap.

\section{PENDAHULUAN}

Indonesia merupakan negara dengan sumber daya alam. Sekitar 30000 jenis tumbuhan yang telah di identifikasi dan 950 jenis diantaranya diketahui memiliki potensi untuk dikembangkan sebagai obat, suplemen makanan, kosmetik dan nutrisi (BPOM RI, 2012). Kosmetik merupakan bahan atau sediaan yang dimaksudkan untuk digunakan pada bagian luar tubuh manusia (epidermis, rambut, kuku, bibir, dan organ genital bagian luar) atau gigi dan membran mukosa mulut terutama untuk membersihkan, mewangikan, mengubah penampilan dan atau memperbaiki bau badan atau melindungi atau memelihara tubuh pada kondisi baik (Chan, 2016). Dalam defenisi kosmetika diatas, yang 
dimaksudkan dengan tidak dimaksudkan untuk mengobati atau menyembuhkan penyakit adalah sediaan tersebut seharusnya tidak mempengaruhi struktur dan faal kulit. Namun, bila bahan kosmetik tersebut merupakan bahan kimia, organ tubuh yang dikenai (ditempel) adalah kulit, maka dalam hal tertentu kosmetika itu akan mengakibatkan reaksi-reaksi dan perubahan faal kulit tersebut. Kulit merupakan organ tubuh yang terletak paling luar dan membatasinya dari lingkungan hidup manusia. Luas kulit orang dewasa sekitar 1,5 $\mathrm{m}^{2}$ dengan berat kira-kira $15 \%$ berat badan. Kulit merupakan organ yang esensial dan vital serta merupakan cermin kesehatan dan kehidupan. Kulit juga sangat kompleks, elastis dan sensitif, serta bervariasi pada keadaan iklim, umur, seks, ras, dan lokasi tubuh (Suhada, 2014)

Upaya atau cara untuk menjaga kulit tetap bersih dan sehat dengan membersihkan seluruh tubuh (mandi) secara teratur. Kenyataan sehari-hari memperlihatkan bahwa kebutuhan mandi memakai sabun mandi adalah ciri manusia modern. Dengan menggunakan sabun maka metabolisme kulit (seperti sebum), lapisan kulit yang mati, residu keringat, kotoran, debu, dan mikroorganisme dapat dihilangkan. Bahkan di saat sekarang ini sabun bukan hanya untuk membersihkan tubuh, tetapi juga sekaligus berfungsi untuk melembutkan kulit, memutihkan kulit, maupun menjaga kesehatan kulit dari efek radikal bebas (Gusviputri, 2013).

Sabun secara umun di definisikan sebagai garam alkali dari asam lemak rantai panjang. Saat lemak dan minyak disaponifikasi terbentuk garam natrium atau kalium dari asam lemak rantai panjang yang di sebut sabun. Sabun adalah surfaktan yang digunakan bersama air untuk membersihkan atau mencuci sesuatu yang tersedia dalam bentuk padat dan cair. Sabun dapat bermanfaat sebagai alat pembersih hal ini disebabkan karena molekul sabun mengandung gugus polar (berikatan dengan air) dan non polar (berikatan dengan minyak) sehingga dapat membersihkan lemak atau kotoran yang tidak dapat terangkat oleh air (Anggraini, 2012 dalam Kartika, 2015).

Dewasa ini, sabun mandi antibakteri sangat diminati oleh masyarakat. Hal ini disebabkan karena dipercaya dapat membersihkan kulit, juga dapat mengobati dan atau mencegah penyakit yang disebabkan oleh bakteri. Dewasa ini pemanfaatan sabun sebagai pembersih kulit makin menjadi trend dan beragam terlihat pada jenis, warna, wangi dan manfaat yang ditawarkan. Berdasarkan jenisnya, sabun dibedakan atas dua jenis yaitu sabun padat (batangan) dan sabun cair. Kulit yang kotor seharian akan memudahkan bakteri untuk menginfeksi. Penambahan bahan atau zat berkhasiat pada sabun diharapkan dapat menghambat pertumbuhan bakteri lebih efektif (Chan, 2016)

Tumbuhan nanas dapat ditanam di kebun, pekarangan, dan tempat lain yang cukup mendapat sinar matahari pada ketinggian 1-1.300 m dpl. Buah masak sifatnya dingin, berkhasiat mengurangi keluarnya asam lambung yang belebihan, membantu mencernakan makanan di lambung, antiradang, peluruh air seni (diuretik), membersihkan jaringan atau sel kulit mati, menghambat pertumbuhan sel kanker, menghambat penggumpalan trombosit (agrerasi platelet), dan mempunyai aktifitas fibrinolitik (Maisarah, 2014).

Pada penelitian (Lestari, 2015) buah nanas (Ananas comosus L.) mengandung asam ananasat, asam sitrat, saponin, flavonoida, polifenol dan enzim bromelain. Selain itu buah 
nanas juga mengandung vitamin $C$ dan vitamin A (Retinol). Kedua vitamin sudah lama dikenal memiliki aktivitas sebagai antioksidan yang mampu menghentikan reaksi berantai pembentukan radikal bebas dalam tubuh. Tubuh manusia kini sangat rentan terhadap pengaruh radikal bebas yang bersumber dari sinar ultraviolet, asap bermotor, bahan pengawet makanan dan lain sebagainya. Jika radikal bebas terbentuk dalam tubuh maka akan terakumulasi dalam jumlah besar dan akan menyerang sel-sel tubuh sehingga terjadilah berbagai penyakit. Buah nanas juga berguna untuk perawatan kulit dan kecantikan. Asam anansat dan asam sitrat yang terkandung pada buah nanas dapat melembutkan dan menyegarkan kulit, enzim bromelin membantu pengelupasan sel kulit mati sehingga kulit terlihat lebih halus dan cerah (Khomsan, 2006; dalam Lestari, 2015). Bromelin terdapat pada tanaman nanas baik dari tangkai, kulit, daun, buah, maupun batang dalam jumlah yang berbeda. Kandungan enzim bromelin lebih banyak terdapat pada batang (bonggol) nanas yang selama ini kurang dimanfaatkan (Anggraini, 2012 ).

Penambahan bonggol nanas merupakan suatu peningkatan dari pengunaan bonggol nanas yang digunakan sebagai bahan kecantikan pada umumnya. Penambahan bonggol nanas pada sabun mandi padat dapat pula meningkatkan nilai guna dari sabun seperti melembabkan, dan melembutkan kulit. Sehingga diperlukan adanya formula yang tepat dalam pembuatan sabun bonggol nanas padat ini, sehingga sabun mandi dari bonggol nanas ini aman dan layak untuk digunakan berdasarkan fisik sabun bonggol nanas padat.

\section{METODE PENELITIAN}

Penelitian ini bersifat penelitian eksperimental. Tempat penelitian adalah laboratorium Formulasi Program Studi S-1 Farmasi Inkes Medistra Lubuk Pakam. Penelitian ini dilakukan selama 3 Bulan.

\section{Sampel Penelitian}

Sampel Penelitian Sampel penelitian ini adalah ekstrak Bonggol Nanas yang diperoleh dari Berastagi. Banyaknya sample yang digunakan dalam penelitian yang digunakan daalam penelitian ini adalah ekstrak Bonggol Nanas yang terdiri dari variasi konsentarsi yang berbeda-beda $3 \%$, $4 \%$ dan $5 \%$.

\section{Alat}

Alat yang digunakan: lumpang dan stamper, beaker glass, penangas air, rotary evaporator, batang pengaduk, neraca analitik, cawan porselen, cawan penguap, pipet tetes, spatula, tabung reaksi, kertas saring, corong, gelas ukur, blender, cetakan sabun, kemasan sabun dan skin analyzer.

\section{Bahan-Bahan}

Bahan yang digunakan: bonggol nanas (Ananas CosmosusL.), etanol $96 \%$, aquadest, minyak kelapa (VCO), $\mathrm{NaOH} 30 \%$, asam stearat, asam sitrat, gliserin, gula, Parfum.

\section{Pelaksanaan Penelitian Pengumpulan Sampel}

Sampel yang digunakan dalam penelitian ini: sampel tumbuhan yang digunakan dipilih secara purposif yaitu tanpa membandingkan tumbuhan yang sama dengan daerah lain. Bahan tumbuhan yang digunakan adalah buah bonggol nanas yang diambil dari daerah Bonggol Nanas yang diperoleh dari Berastagi, Kabupaten Karo, Sumatera Utara. 


\section{Pembuatan Ekstrak Etanol Bonggol Nanas}

Bonggol Nanas dipotong-potong, lalu Bonggol Nanas tersebut di blender hingga halus, setelah semuanya diblender, Bonggol Nanas tersebut dimaserasi dengan etanol $96 \%$ selama lima hari sambil di aduk dan disimpan di tempat yang tidak terkena cahaya matahari. Kemudian di serkai, ampasnya di rendam kembali selama dua hari, lalu di serkai kembali dan ampasnya di buang. Kemudian hasil rendaman tersebut di rotary evaporator hingga menjadi ekstrak kental.

\section{Pembuatan Formulasi Sabun Padat}

Formulasi Sabun Padat

$\begin{array}{lll}\text { R/ Minyak kelapa } & 5 & \mathrm{~g} \\ \text { NaOH 30\% } & 9 & \mathrm{~g} \\ \text { Gula } & 3,75 & \mathrm{~g} \\ \text { Asam stearat } & 3,5 & \mathrm{~g} \\ \text { Asam sitrat } & 1,5 & \mathrm{~g} \\ \text { Gliserin } & 6,5 & \mathrm{~g} \\ \text { Etanol } 96 \% & 7,5 & \mathrm{~g} \\ \text { Aquadest } & 2,25 & \mathrm{~g} \\ \text { Ekstrak bonggol nanas } & \mathrm{x} \% & \\ \text { Parfum } & 16 & \mathrm{cc}\end{array}$

Keterangan: $\mathrm{x}=$ Ekstrak bonggol nanas

$$
3 \%, 4 \%, 5 \%
$$

Cairkan Asam stearat lalu tambahkan minyak VCO, aduk hingga homogen, tambahkan $\mathrm{NaOH} 30 \%$ diaduk hingga homogen ditambahkan Etanol $96 \%$ diaduk, ditambahkan Asam sitrat diaduk, ditambahkan gliserin diaduk, ditambahkan gula yang telah dilarutkan aduk. Dituang ke dalam cetakan dan didiamkan selama 1 sampai 2 hari sampai mengeras, kemudian sabun digunakan sebagai penelitian selanjutnya.

\section{Pemeriksaan Sabun Mandi Padat}

Pemeriksaan sediaan sabun mandi padat dilakukakan dengan cara metode uji kesukaan, pengujian $\mathrm{pH}$, dan uji iritasi terhadap sukarelawan.

\section{Pengujian Iritasi Terhadap Kulit Sukarelawan}

Percobaan dapat dilakukan pada 10 orang sukarelawan. Dengan cara: Sediaan sabun mandi padat dioleskan pada telinga bagian belakang sukarelawan,kemudian dibiarkan selama \pm 1 jam, dan dilihat perubahan yang terjadi, berupa iritasi pada kulit, gatal, panas, kering, kemerahan dan perkasaran.

\section{Pengujian pH Pada Sediaan}

Pengujian $\mathrm{pH}$ adalah parameter pengujian mutu dari sabun padat. Kulit yang normal memiliki $\mathrm{pH}$ yang relatif asam yaitu 5,9-6,5. Kulit memiliki $\mathrm{pH}$ yang relatif asam ini terdiri atas asam laktat, asam amino, asam lemak bebas, asam karbonsiklik dan potassium yang berasal dari keringat, kelenjar serbaseus dan serbum proses pembentukan keratin pada kulit.

\section{Pengujian Skrining Fitokimia Simplisia}

Pemeriksaan flavonoida

Sebanyak 10 gram simplisia ditambahkan $10 \mathrm{ml}$ air, didihkan selama 5 menit dan disaring dalam keadaan panas, kedalam $5 \mathrm{ml}$ filtrat ditambahkan 0,1 gram serbuk magnesium dan $1 \mathrm{ml}$ asam klorida pekat dan $2 \mathrm{ml}$ amil alkohol, dikocok dan dibiarkan memisah. Flavonoida positif jika terjadi warna merah, kuning, jingga pada lapisan amil alkohol (Farnsworth, 1996 dalam Kaban, 2015).

Pemeriksaan saponin

Sebanyak 0,5 gram sampel dimasukkan dalam tabung reaksi dan ditambahkan $10 \mathrm{ml}$ air suling panas, didinginkan kemudian dikocok kuatkuatselama 10 detik, timbulbusa yang mantap tidak kurang dari 10 menit setinggi $1-10 \mathrm{~cm}$. Tambahkan 1 tetes larutan asam klorida $2 \mathrm{~N}$, bila buih tidak 
hilang menunjukan adanya saponin (Depkes RI, 1989 dalam Kaban, 2015).

\section{Pengujian Kemampuan Sediaan Untuk Melembabkan Kulit.}

Kemampuan sediaan untuk melembabkan kulit dilakukan pada sukarelawan yang mempunyai kriteria sama dengan sukarelawan untuk uji iritasi, menggunakan alat Skin Moisture Analyzer dengan cara berikut: Punggung tanggan terlebih dahulu di cuci bersih, kemudian dikeringkan hingga benar-benar kering. Dicek persen kelembapan kulit sebelum dioleskan sediaan sabun, dan dicatat persentase yang ditunjukan pada alat.Sediaan sabun dioleskan merata pada punggung tangan. Dibiarkan hingga sediaan sabun benar-benar meresap pada kulit \pm 1 jam. Dicek kembali persen kelembapan setelah dioleskan sediaan krim, dicatat persentase yang ditunjukan. Diulangi pengolesan kedua, dan diulangi hingga pengolesan ketiga, dicatat persentase yang ditunjukan. Dihitung rata-rata yang diperoleh.

\section{HASIL DAN PEMBAHASAN}

Hasil Skrining dan Ekstraksi Bonggol Nanas

Hasil yang didapat dari proses skrining fitokimia dapat dilihat pada Tabel 1.

Tabel 1. Hasil pengujian Skrining Fitokimia

\begin{tabular}{|c|c|c|}
\hline No. & $\begin{array}{c}\text { Ekstrak } \\
\text { Bonggol } \\
\text { Nanas }\end{array}$ & Keterangan \\
\hline 1 & Flavonoid & $(+)$ Jingga \\
\hline 2 & Saponin & $\begin{array}{l}(+) \text { Buih tidak } \\
\text { hilang }\end{array}$ \\
\hline
\end{tabular}

Sedangkan hasil ekstraksi dari 500 $\mathrm{ml}$ bonggol nanas dengan menggunakan pelarut etanol $96 \%$ dengan rotary evaporator pada suhu $\pm 78^{\circ} \mathrm{C}$ yaitu berupa ekstrak $180 \mathrm{ml}$.

\section{Hasil Penentuan Mutu Sediaan Hasil Pengukuran pH Sediaan Sabun}

Hasil pengukuran $\mathrm{pH}$ sabun ekstrak bonggol nanas yang dilakukan dengan menggunakan $\mathrm{pH}$ meter pada berbagai konsentrasi, didapat perbedaan ukuran $\mathrm{pH}$ yang dapat dilihat pada Tabel 2 .

Data pengukuran $\mathrm{pH}$ sabun berdasarkan hari

Tabel 2. Hasil Pengukuran $\mathrm{pH}$

\begin{tabular}{ccccc}
\hline Formulasi & \multicolumn{5}{c}{ Nilai pH pada hari } \\
& \multicolumn{5}{c}{$\mathbf{k e}$} \\
\cline { 2 - 5 } F1 & $\mathbf{0}$ & $\mathbf{1}$ & $\mathbf{3}$ & $\mathbf{7}$ \\
F2 & 9,0 & 9,0 & 9,0 & 9,0 \\
F3 & 9,6 & 9,3 & 9,3 & 9,3 \\
Dilihat & dari & Tabel & 2.6 & bahwa
\end{tabular}

terdapat perbedaan ukuran $\mathrm{pH}$ yang dihasilkan dengan variasi dengan variasi konsentrasi ekstrak bonggol nanas yang ditambahkan pada formula sabun. Hasil penelitian menunjukkan bahwa selama 1 minggu tidak terdapat perubahan $\mathrm{pH}$. Hasil penelitian menunjukkan bahwa F3 dengan konsentrasi ekstrak bonggol nanas 5\% menyebabkan $\mathrm{pH}$ meningkat menjadi 9,6 atau lebih tinggi dibandingkan dengan peningkatan $\mathrm{pH}$ pada $\mathrm{F} 1$ (konsentrasi $3 \%$ ) dan F2 (konsentrasi $4 \%$ ) yang $\mathrm{pH}$ nya hanya sebesar 0,03 .

\section{Hasil Uji Iritasi Terhadap Responden}

Penggunaan kosmetik yang tidak baik pada kulit dapat menyebabkan berbagai reaksi ( efek samping ). Untuk mengetahui ada tidaknya efek samping tersebut maka dilakukan uji iritasi terhadap kulit. Berdasarkan penelitian 
yang dilakukan maka diperoleh hasil sebagaimana tabel 3 dibawah ini:

Tabel 3. Hasil Uji Iritasi Terhadap Responden

\begin{tabular}{|c|c|c|}
\hline Pengujian & Respon & Keterangan \\
\hline \multirow[t]{2}{*}{ Kemerahan } & $\mathrm{I}$ & - \\
\hline & II & - \\
\hline \multirow[t]{2}{*}{ Gatal } & III & - \\
\hline & IV & - \\
\hline \multirow[t]{2}{*}{ Panas } & V & - \\
\hline & VI & - \\
\hline \multirow[t]{2}{*}{ Kering } & VII & - \\
\hline & VIII & - \\
\hline \multirow[t]{2}{*}{ Kasar } & IX & - \\
\hline & $X$ & - \\
\hline
\end{tabular}

Menurut Wasitaatmadja 1997 dalam purba 2016, pengujian iritasi terhadap kulit untuk mengetahui ada atau tidaknya efek samping, dilakukan dengan cara sabun dioleskan pada lengan bawah atau di belakang telinga, kemudian dibiarkan selama \pm 1 jam dan dilihat perubahan yang terjadi berupa kemerahan, gatal, kasar, panas dan kering. Dari data tabel diatas, ternyata tidak terli hat adanya efek samping berupa kemerahan, gatal, kasar, panas, dan kering pada kulit yang ditimbulkan oleh sediaan. Maka dapat di simpulkan sediaan sabun mandi padat dari ekstrak etanol bonggol nanas tidak menyebabkan iritasi kulit.

\section{Hasil Kemampuan Sediaan Untuk Melembabkan Kulit}

Hasil kemampuan sediaan untuk melembabkan kulit dapat dilihat di tabel 4. Tabel 4. menunjukkan kemampuan sediaan untuk meningkatkan kelembaban kulit yang ditentukan dengan menggunakan alat skin analyzer. Pengukuran kelembaban awal dilakukan sebelum sediaan digunakan, selanjutnya dilakukan pengukuran kelembaban pada kulit bagian punggung tangan yang diuji setelah penggunaan \pm 1 jam. Hal ini bertujuan untuk melihat seberapa besar pengaruh sabun mandi dengan ekstrak bonggol nanas dalam perubahan yang terjadi pada kulit (Rafiud, 2016).

Data hasil pegukuran kelembaban pada kulit awal, setelah pemakaian sabun selama \pm 1 jam.

Tabel 4. Hasil pegukuran kelembaban kulit

\begin{tabular}{|c|c|c|c|}
\hline \multirow[t]{2}{*}{ Formulasi } & \multirow[t]{2}{*}{ Respon } & \multicolumn{2}{|c|}{ Kelembapan kulit } \\
\hline & & Sebelum & Sesudah \\
\hline \multirow[t]{2}{*}{ Blanko } & I & $\begin{array}{c}30,06 \\
\%\end{array}$ & $38,01 \%$ \\
\hline & II & $\begin{array}{c}29,09 \\
\%\end{array}$ & $34,05 \%$ \\
\hline \multirow{3}{*}{$\begin{array}{c}\text { Rata-rata } \\
\text { Kontrol } \\
\text { Positif }\end{array}$} & & $29,57 \%$ & $36,03 \%$ \\
\hline & I & $\begin{array}{c}35,01 \\
\%\end{array}$ & $60,01 \%$ \\
\hline & II & $\begin{array}{c}32,05 \\
\%\end{array}$ & $63,04 \%$ \\
\hline Rata-rata & & $33,53 \%$ & $61,75 \%$ \\
\hline \multirow[t]{2}{*}{ Kons. 3\% } & $\mathrm{I}$ & $29,08 \%$ & $40,08 \%$ \\
\hline & II & $27,08 \%$ & $45,09 \%$ \\
\hline Rata-rata & & $28,08 \%$ & $42,58 \%$ \\
\hline \multirow{2}{*}{ Kons. 4\% } & $\mathrm{I}$ & $30,33 \%$ & $47,02 \%$ \\
\hline & II & $28,99 \%$ & $49,01 \%$ \\
\hline Rata-rata & & $29,66 \%$ & $48,01 \%$ \\
\hline \multirow[t]{2}{*}{ Kons. 5\% } & I & $38,12 \%$ & $50,02 \%$ \\
\hline & II & $37,07 \%$ & $51,03 \%$ \\
\hline Rata-rata & & $37,59 \%$ & $50,52 \%$ \\
\hline
\end{tabular}

Keterangan :

Blanko : Sediaan tidak mengandung ekstrak bonggol nanas

Kontol positif : Sediaan yang tersedia dipasaran

Formulasi $1(\mathrm{~F} 1) \quad$ : Sediaan yang mengandung $3 \%$ ekstrak bonggol nanas

Formulasi 2 (F2) : Sediaan yang mengandung $4 \%$ ekstrak bonggol nanas

Formulasi 3 (F3) : Sediaan yang mengandung $5 \%$ ekstrak bonggol nanas 
Secara umum, terlihat bahwa setiap formulasi menunjukkan peningkatan persentase kelembaban sebelum penggunaan dan setelah penggunaan sabun, persentase kelembaban semakin meningkat dengan bertambahnya waktu penggunaan sabun, hal ini dapat dilihat bahwa presentase kelembaban pada tiap formulasi meningkat setelah pemakaian.Namun, peningkatan persentase kelembaban berbeda pada tiap formulasi.Untuk setiap kosenterasi semakin tinggi konsentrasi semakin tinggi kelembapan kulitnya.

\section{SIMPULAN DAN SARAN}

\section{Simpulan}

Berdasarkan hasil penelitian yang telah dilakukan dapat disimpulkan bahwa:

1. Sediaan sabun mandi padat yang mengandung ekstrak etanol bonggol nanas (Ananas Cosmosus L) dapat di formulasikan kedalam sediaan sabun mandi padat, seluruh formula dengan jus bonggol nanas 3\%, 4\%, 5\% dan Blanko.

2. Sediaan sabun mandi padat dari ekstrak bonggol nanas mempunyai kemampuan untuk melembabkan kulit, dan yang paling besar di peroleh pada konsentrasi $5 \%$ dengan kelembapan 57,83 \% dapat melembabkan kulit dan tidak mengiritasi kulit dan pada konsentrasi $4 \%$ dengan kelembapan $48,3 \%$ juga dapat melembabkan kulit tetapi dengan tingkat kelembapan yang sedang, dan pada formulasi $3 \%$ dengan kelembapan $43,33 \%$ juga dapat melembabkan kulit tetapi dengan tingkat kelembapan yang lebih rendah.

\section{Saran}

Diharapkan untuk penelitian selajutnya agar dapat membuat sediaan lainnya dari ekstrak etanol bonggol nanas (Ananas Cosmosus L) dalam bentuk sediaan lain seperti sabun cair, lotion, sabun transparan, lulur, krim dan sebagainya.

\section{DAFTAR PUSTAKA}

\section{Buku:}

BPOM RI. (2012). Pedoman Teknologi Formulasi Sediaan Berbasis Ekstrak. Volume I. Jakarta: Direkorat OAI, Deputi II, Badan POM RI.

Kartika Andansari. (2015). Analisis Ekuitas Merek Sabun Mandi Kesehatan Lifebuoy Dikota Bogor. Skripsi. Bogor. Institut Pertanian Bogor.

Maisarah. (2014). Panduan Praktis Budidaya Nanas. Yogyakarta: Indopublika. Halaman 2-5,1117

Purba, R.Y (2016). Skrining Fitokimia dan Penggunaan Buah Belimbing Manis (Averrhoa caranbola L). Sebagai Pelembab Dalam Krim cair Tangan Dan Badan. Skripsi. Medan. Universitas Tjut Nyak Dhien.

Setiawan, H.M (2015). Isolasi Dan Uji Daya Antimikroba Ekstrak Kulit Nanas (Ananas comosus. L). Skripsi. Semarang. Universitas Negri Semarang

Suhada Tri. (2014). Efek esktrak kulit manggis (Garcinia mangostana. L) Sebagai Anti Aging dalam Sediaan Krim. Skripsi. Medan. FMIPA USU.

\section{Jurnal:}

Anggraini Deni. (2012). Formulasi Sabun Cair dari Ekstrak Batang Nanas (Ananas comosus.L) untuk Mengatasi Jamur Candida albicans. Jurnal. 
Sekolah Tinggi Ilmu Farmasi Riau, Pekanbaru, Riau, Indonesia.

Chan Adek. (2016). Formulasi Sediaan Sabun Mandi Padat dari Ekstrak Buah Apel (Malus domesticus). Jurnal. Medan: jurusan farmasi. Helvetia Sari Mutiara.

Lestary, M.Y (2015). Carbomer 980 In Pineapple (Ananas comosus. L) Juice Peel-Off Mask Gel. Jurnal. Jakarta. Fakultas Farmasi dan Sains UHAMKA.

Rafiud.A, A (2016). Formulasi Sabun Padat Dengan Kombinasi Tepung Beras dan Ekstrak Daun Kemuning (Murraya Paniculata L. jack) Sebagai Antibakteri

Gusviputri Arwinda. (2013). Pembuatan Sabun Dengan Lidah Buaya (Aloe Vera) Sebagai Antiseptik Alami. Jurnal. Surabaya. Universitas Khatolik Widya Mandala Surabaya.

Kaban, Rani. (2015). Uji Aktivitas Antibakteri Ekstrak Etanol Daun Binara dan EkstrakEtanol Daun Ulam-Ulam Terhadap Bakteri (Staphylococcus aureus dan Escherichia coli). Skripsi. Medan: Fakultas Farmasi Universitas Sumatra Utara.

\section{Artikel online:}

Cowan, Murphy. (2014). Plant Products as Antimirobial Agents. Clinical Microbiology Review

Amid, Azura. (2011). Expression, purification, and characterization of a recombinant stem bromelain from Ananas comosus. Elsevier. Process Biochemistry

Cagno, Raffaella, (2010). Taxonomic structure of the yeasts and lactic acid bacteria microbiota of pineapple (Ananas comosus L. Merr.) and use of autochthonous starters for minimally processing. Elsevier. Food Microbiology

Gangopadhyay, G. (2015). Pineapple (Ananas comosus (L.) Merr)

Mohanta T.K., Tamboli Y., Zubaidha P.K. (2014). Phytochemical and medicinal importance of Ginkgo biloba L. Nat. Prod. Res. 